ARTICLE

https://doi.org/10.1038/s41467-019-09946-9

\title{
Copper-containing glass ceramic with high antimicrobial efficacy
}

Timothy M. Gross ${ }^{1}$, Joydeep Lahiri ${ }^{1}$, Avantika Golas (1) ${ }^{1}$, Jian Luo ${ }^{1}$, Florence Verrier ${ }^{1}$, Jackie L. Kurzejewski ${ }^{1}$, David E. Baker ${ }^{1}$, Jie Wang${ }^{2}$, Paul F. Novak \& Michael J. Snyder ${ }^{1}$

Hospital acquired infections (HAls) and the emergence of antibiotic resistant strains are major threats to human health. Copper is well known for its high antimicrobial efficacy, including the ability to kill superbugs and the notorious ESKAPE group of pathogens. We sought a material that maintains the antimicrobial efficacy of copper while minimizing the downsides - cost, appearance and metallic properties - that limit application. Here we describe a copper-glass ceramic powder as an additive for antimicrobial surfaces; its mechanism is based on the controlled release of copper (I) ions $\left(\mathrm{Cu}^{1+}\right)$ from cuprite nanocrystals that form in situ in the water labile phase of the biphasic glass ceramic. Latex paints containing copper-glass ceramic powder exhibit $\geq 99.9 \%$ reduction in $S$. aureus, $P$. aeruginosa, K. aerogenes and E. Coli colony counts when evaluated by the US EPA test method for efficacy of copper-alloy surfaces as sanitizer, approaching that of benchmark metallic copper.

\footnotetext{
${ }^{1}$ Corning Incorporated, Corning, NY 14831, USA. ${ }^{2}$ Argonne National Laboratory, Argonne, IL 60439, USA. Correspondence and requests for materials should be addressed to T.M.G. (email: grosstm@corning.com) or to J.L. (email: lahirij@corning.com)
} 
$\mathrm{N}$ osocomial infections and the emergence of antibioticresistant strains pose significant clinical and economic challenges $^{1,2}$. While good hygiene practices are the bedrock for infection control, emerging evidence suggests that continuously killing antimicrobial surfaces based on metallic copper can reduce bioburden and lower the risk of infection ${ }^{3}$. Copper's multiple mechanisms of action, which includes the ability to destroy genomic and plasmid $\mathrm{DNA}^{4}$, explain its longstanding antimicrobial efficacy against pathogens such as antibiotic-resistant "superbugs" 5, 6. Proposed mechanisms for copper-mediated cellular damage and toxicity include direct cell membrane damage, the generation of reactive hydroxyl radicals through Fenton-type reactions, and entry of copper ions into cells through ligand interactions causing disruption of RNA and DNA function ${ }^{5-7}$. While the precise mechanism is unclear, $\mathrm{Cu}^{1+}$ ions are considerably more toxic to bacteria than $\mathrm{Cu}^{2+}$ ions under test conditions that mimic microbial contamination on solid surfaces ${ }^{8-10}$.

There has been a significant focus on metallic copper as an antimicrobial since the US EPA introduced a new test protocol in 2008 that was exclusively passed by copper surfaces ${ }^{11}, 12$. The US EPA mandated that claims of efficacy against human pathogens could only be obtained for products that pass the standard with the justification that it was a realistic simulation of contamination unlike the traditional test ${ }^{6}, 13$. We wanted to make a coppercontaining additive compatible with commonly used surfaces and coatings that demonstrated the efficacy to kill $\geq 99.9 \%$ of bacteria under EPA's test conditions retaining copper's broad spectrum efficacy and low probability for the development of resistant strains 5,14

We describe an alkali copper aluminoborophosphosilicate glass ceramic material that acts as a sustainable delivery system for $\mathrm{Cu}$ +1 ions with high antimicrobial efficacy. We use paint coatings as a first-case demonstrative application due to their ubiquity. Paint coatings containing the copper-glass ceramic powder exhibit $\geq 99.9 \%$ reduction in $S$. aureus, $P$. aeruginosa, $K$. aerogenes, and $E$. coli colony counts using the US EPA test method. The copper-glass ceramic is advantaged over existing organic antimicrobial paint additives owing to a favorable toxicological profile and copper's broad-spectrum efficacy. Unlike air and moisture sensitive cuprous compounds, the copper-glass ceramic is environmentally stable and disperses easily in water. Our work showcases an effective and versatile antimicrobial additive with potential application in coatings and plastics. It also demonstrates rational glass design as an approach for the practical synthesis of functional nanomaterials.

\section{Results and discussion}

Copper-glass and copper-glass ceramic compositions. We investigated copper-containing glasses because we hypothesized that the excellent barrier properties of glass to gaseous oxygen ${ }^{15}, 16$ would stabilize the environmentally labile $\mathrm{Cu}^{1+}$ ions. Copper in aluminosilicate glasses has been described and demonstrated to contain $>70 \%$ of copper in the $\mathrm{Cu}^{1+}$ state ${ }^{17,18}$. Since monovalent ions within glasses can be extracted via an ion exchange process with $\mathrm{H}_{3} \mathrm{O}^{+}$ions ${ }^{19,}{ }^{20}$, this system was a promising starting point for the design of antimicrobial glasses. The initial composition that was melted was batched as $60 \mathrm{SiO}_{2}-20 \mathrm{Al}_{2} \mathrm{O}_{3}-20 \mathrm{CuO}$ ("Methods"). The analyzed composition for this glass (Sample A) is provided in Table 1. Our copper redox analysis using inductively coupled plasma-optical emission spectroscopy (ICP-OES) for total copper and $\mathrm{Cr} / \mathrm{Cu}$ redox reaction for total $\mathrm{Cu}^{1+}$ indicated that the ratio of $\mathrm{Cu}^{1+}$ to total copper was 0.86 for the copper-glass. Unlike previous experiments aimed at reducing copper ${ }^{21}$, the melting was not performed under a reducing atmosphere or with batched reducing agents. The reduction of copper from $\mathrm{Cu}^{2+}$ in the batched material to $\mathrm{Cu}^{1+}$ in the final glass was attributed to the high melting temperature and the nominally reducing conditions attributed to the glass composition. Glass compositions rich in high field strength cations such as $\mathrm{Si}^{4+}$ and $\mathrm{B}^{3+}$ have a strong reducing effect on multivalent ions incorporated into the glass melt ${ }^{22}$. Unfortunately, the glass, when milled into a powder and mixed into paint, did not show the desired antimicrobial potency. We hypothesized that the small ionic size of $\mathrm{Cu}^{1+}(r=0.60 \AA)^{23}$ would limit the ion exchange reaction with larger $\mathrm{H}_{3} \mathrm{O}^{+}(r=1.4 \AA)^{24}$ as the extraction mechanism. When a glass is cooled from the molten state, the oxygen packing density of the glass network is increased as ionic field strength of modifier ions such as $\mathrm{Cu}^{1+}$ increases, resulting in smaller interstitial spaces surrounding the modifiers. Since inter-diffusion of charged species requires charge neutrality ${ }^{25}$, the $\mathrm{H}_{3} \mathrm{O}^{+} / \mathrm{R}^{1+}(\mathrm{R}=\mathrm{Li}, \mathrm{Na}, \mathrm{K}, \mathrm{Cu}$, etc. $)$ ion exchange is effectively stopped if the larger ion cannot enter the site that forms around the smaller, higher field strength ion. Figure $1 \mathrm{a}, \mathrm{b}$ shows structures of two model glasses with compositions of $60 \mathrm{SiO}_{2}-20 \mathrm{Al}_{2} \mathrm{O}_{3}-20 \mathrm{Cu}_{2} \mathrm{O}$ and $60 \mathrm{SiO}_{2}-20 \mathrm{Al}_{2} \mathrm{O}_{3}-20 \mathrm{~K}_{2} \mathrm{O}$ obtained through molecular dynamics simulations ("Methods"). The structures demonstrate the steric constraints that limit ion exchange between $\mathrm{H}_{3} \mathrm{O}^{+}$ions with $\mathrm{Cu}^{1+}$ but not with $\mathrm{K}^{+}(r=$ $1.4 \AA)^{24}$, consistent with experimental observation ${ }^{26}$. Thus, while the initial ternary glass contained significant amounts of $\mathrm{Cu}^{1+}$ ions, there was no mechanism to effectively extract these ions from the glass for antimicrobial activity.

To overcome the antimicrobial inefficacy of $\mathrm{Cu}^{1+}$-containing glasses, we considered a new approach. The concept was to design a glass that phase separates into a highly durable matrix phase and a lower durability second phase that contains the monovalent copper. We reduced the $\mathrm{Al}_{2} \mathrm{O}_{3}$ content in the glass and replaced it with $\mathrm{K}_{2} \mathrm{O}, \mathrm{B}_{2} \mathrm{O}_{3}$, and $\mathrm{P}_{2} \mathrm{O}_{5} . \mathrm{Al}_{2} \mathrm{O}_{3}$ suppresses phase separation in most glass systems, while additions of alkali oxide, $\mathrm{B}_{2} \mathrm{O}_{3}$, and $\mathrm{P}_{2} \mathrm{O}_{5}$ have the opposite effect ${ }^{27}$. The results of several iterations (Samples B-F, Table 1) are shown in Table 1. The level of $\mathrm{Cu}$ + /total copper remains approximately the same (0.8-0.9) across the samples; we believe that the high melting temperature and silica-rich environment common to all the samples drives that ratio. Low levels of potassium inclusion (Samples B) were insufficient to significantly increase the antimicrobial potency; a marginal increase in potency was observed when approximately $10 \mathrm{~mol} \%$ of $\mathrm{Al}_{2} \mathrm{O}_{3}$ was replaced by $\mathrm{K}_{2} \mathrm{O}$ (Sample $\mathrm{C}$ ). The formation of cuprite crystals was observed by powder $\mathrm{X}$-ray diffraction (XRD) at this level of substitution. Higher $\mathrm{Al}_{2} \mathrm{O}_{3}$ content stabilizes monovalent cations such as $\mathrm{Cu}^{1+}$ in the glassy phase in a charge compensating role, which presumably necessitates lowering $\mathrm{Al}_{2} \mathrm{O}_{3}$ levels significantly for cuprite crystal formation $^{27}$. Further substitution of $\mathrm{Al}_{2} \mathrm{O}_{3}$ by $\mathrm{B}_{2} \mathrm{O}_{3}$ (Sample D) was made to induce phase separation, but this effect was not observed until $\mathrm{P}_{2} \mathrm{O}_{5}$ was also introduced (Sample E). This biphasic glass containing cuprite showed a major improvement in antimicrobial potency relative to the previous samples. An exemplary composition based on sample $\mathrm{E}$ that also included a higher level of copper (Sample F) was shown to have $>99.999 \%$ efficacy under EPA's test conditions. This material had a distinct orange color. XRD confirmed that the crystalline phase was cuprite $\left(\mathrm{Cu}_{2} \mathrm{O}\right)$ for sample $\mathrm{E}$ (Fig. 2a inset). Since this composite material contains both amorphous and crystalline regions, it is generally referred to as a glass ceramic. Figure $2 \mathrm{a}, \mathrm{b}$ are scanning electron microscopic (SEM) images of the material before and after exposure to water, respectively. The lower durability glassy phase regions containing the bright crystalline facets of cuprite crystals ( $300 \mathrm{~nm}$; Fig. 2a) are replaced to a large extent by 


\section{Table 1 Copper-glass and copper-glass ceramic compositions}

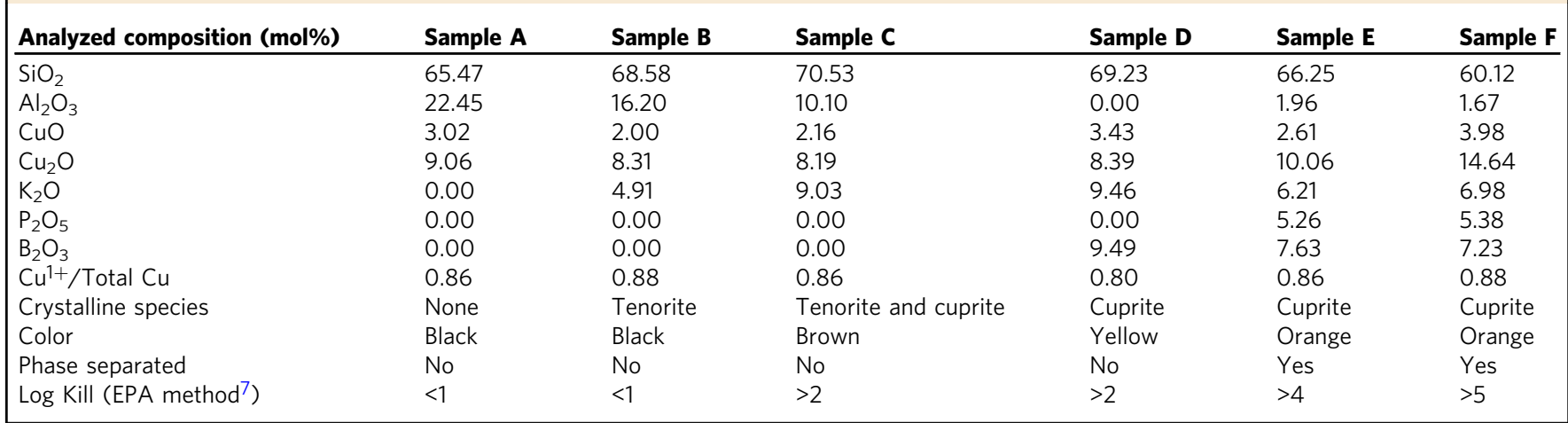

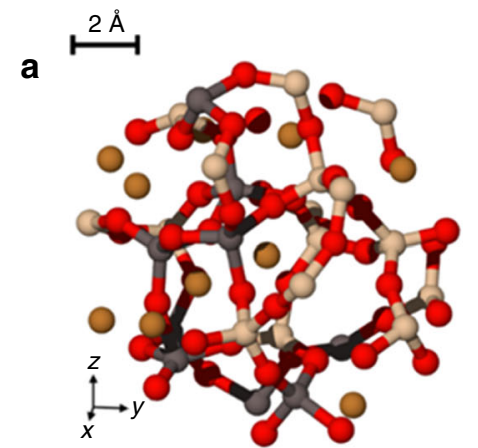

b

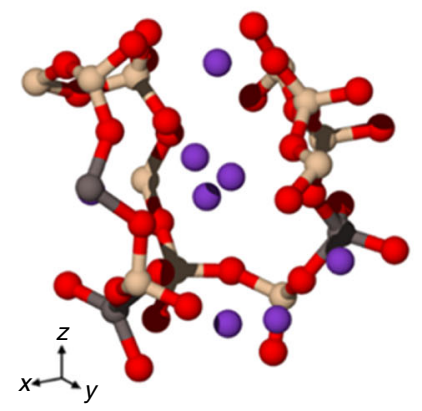

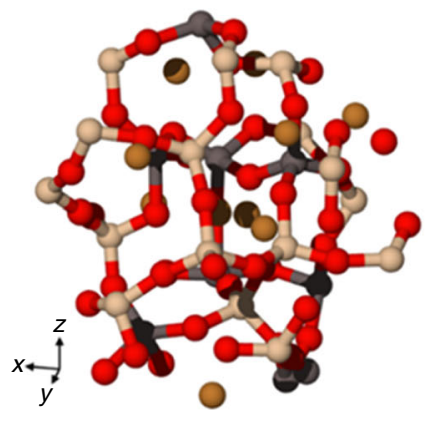

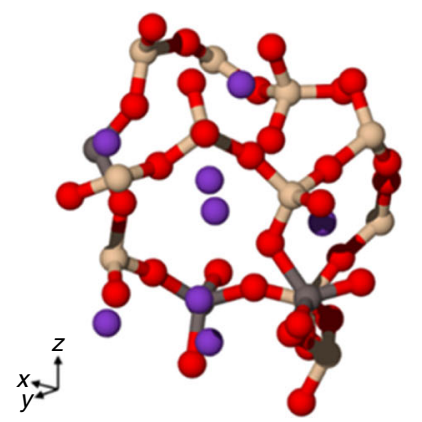

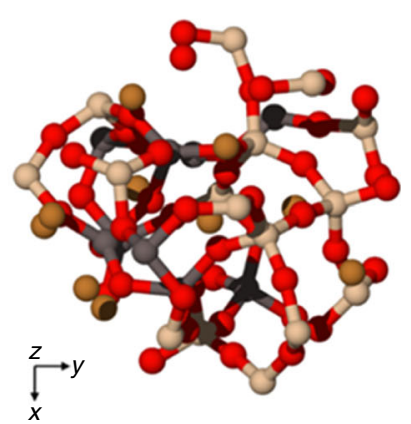

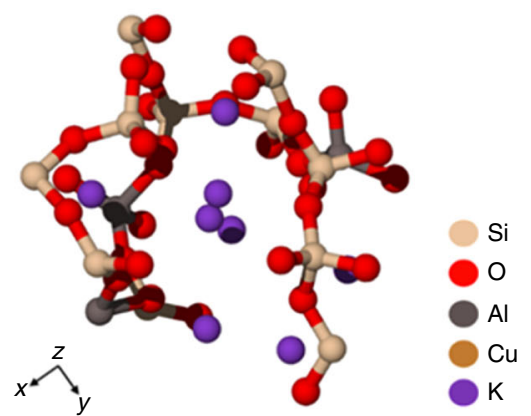

Fig. 1 Structures of two model glass compositions by molecular dynamics simulations a Model glass with composition of $60 \mathrm{SiO}_{2}-20 \mathrm{Al}_{2} \mathrm{O}_{3}-20 \mathrm{Cu} \mathrm{O}_{2}($ in mol\%). The model shows a tightly packed glass network structure surrounding small, high-field strength copper (I) ions. b Model glass with composition of $60 \mathrm{SiO}_{2}-20 \mathrm{Al}_{2} \mathrm{O}_{3}-20 \mathrm{~K}_{2} \mathrm{O}$ (in mol\%). The model reveals a more open glass network structure surrounding larger, lower-field strength $\mathrm{K}^{+}$ions. The high oxygen packing density of glass networks formed around small radius, high ionic field strength modifier ions (as in a) reduces the capability for ion exchange with charged water species

cavities (Fig. 2b), indicating the release of some of the cuprite crystals from the material. Dissolution of the lower durability phase leads to tunneling into the subsurface with separated discontinuous phases becoming connected and providing additional access to cuprite crystals. Figure 3 is a scanning transmission electron microscopic (STEM) image of the material: the darkest region is the continuous glassy phase, the next lighter regions are the discontinuous glassy regions, and the brightest regions are the faceted cuprite crystals. Composition mapping by electron-dispersive spectroscopy (EDS) shows that the continuous glassy matrix phase is composed primarily of silica while the discontinuous phase containing the cuprite crystals is enriched in phosphorus, boron, and potassium. The dissolution of the discontinuous phase was further proven by analysis of the leached ions measured by ICP-MS. High concentrations of potassium, phosphorus, and boron were observed; conversely, $\mathrm{Al}$ ions, presumably present in the silica-rich continuous phase, were present at very low concentrations (Supplementary Table 1).
We hypothesize that the discontinuous phase undergoes facile ion exchange between $\mathrm{K}^{+}$and $\mathrm{H}_{3} \mathrm{O}^{+}$ions followed by the impregnated water molecules participating in hydrolysis reactions that break oxygen-phosphorus bonds. The hydrolysis reaction has been shown to preferentially take place at $\mathrm{Q}^{3}$ groups, i.e., phosphorous atoms linked into the network by three bridging oxygen atoms ${ }^{28}$. The breaking of the chains at $\mathrm{Q}^{3}$ locations depolymerizes the phosphorous glass network to release the cuprite crystals. The continuous silica-rich network tempers access to the dispersed phosphorus-rich phase deeper in the particles enabling the overall controlled release of copper ions from the material. We cannot rule out some limited leaching of copper ions from cuprite crystals in the durable silica-rich phase.

Antimicrobial efficacy of copper-glass ceramic particles. Copper-glass ceramic particles were air jet-milled with no size classification for reasons of scalability and economics. This gave a particle size $d_{50}$ ranging from 2.5 to $5.0 \mu \mathrm{m}$. Milled particles were 
a

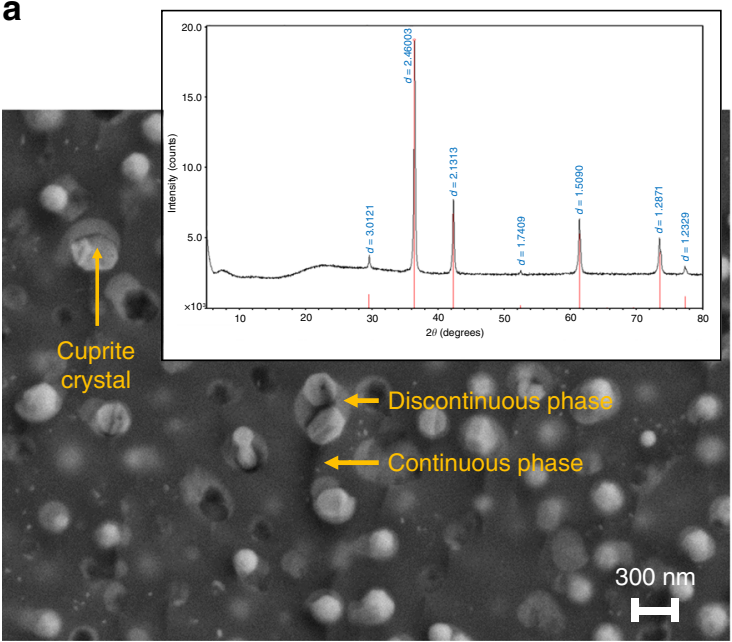

b

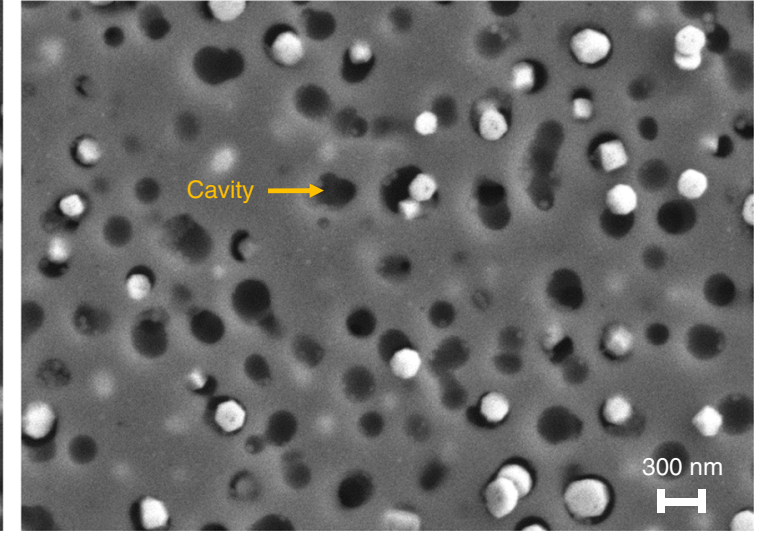

Fig. 2 Scanning electron microscope (SEM) images of copper-glass ceramic cross-section before and after exposure to water a Cross-section of the copper-glass ceramic shown prior to water exposure reveals a continuous glassy phase, a discontinuous glassy phase, and a cuprite crystalline phase trapped in the discontinuous phase. Inset is X-ray diffraction (XRD) data collected on copper-glass ceramic powder which shows that the crystalline species present is cuprite. b Cross-section of the copper-glass ceramic shows the formation of cavities following water exposure ( 120 min) due to dissolution of the discontinuous glassy phase that lead to the release of cuprite crystals into solution

.

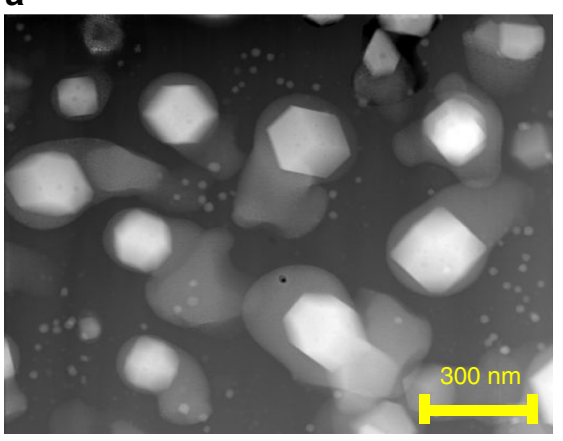

b

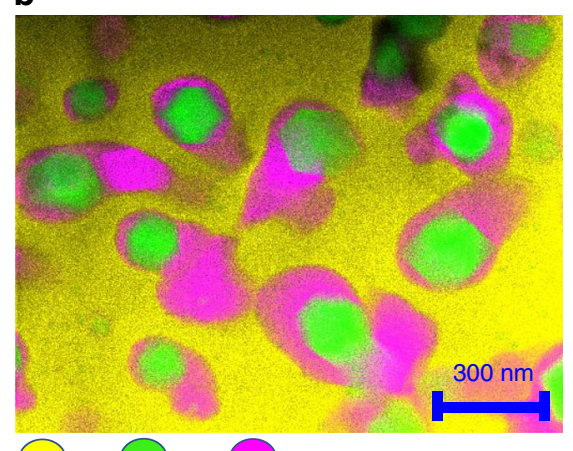

C

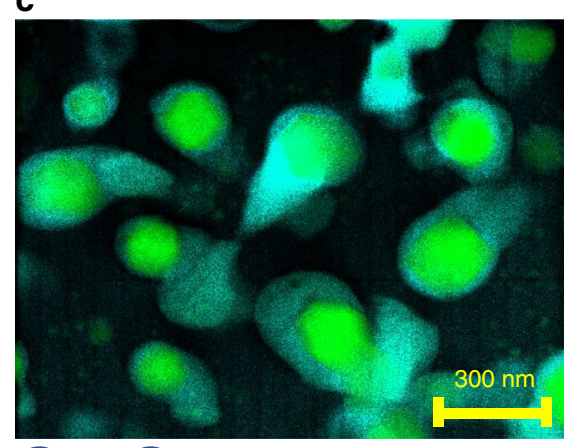

$\mathrm{cu} \bigcirc \mathrm{k}$

Fig. 3 Elemental mapping of chemical species in microstructure of copper-glass ceramic Energy-dispersive X-ray spectroscopy (EDS) using a scanning transmission electron microscope was used for elemental mapping. a A microstructural view of the copper-glass ceramic highlighting the three phases present. Some smaller cuprite crystals are also observed in the continuous phase. b EDS elemental mapping shows that the high durability, continuous matrix phase is enriched in silicon, the lower durability, discontinuous phase in enriched in phosphorous, and the crystals are composed of copper. c EDS elemental mapping also reveals that the lower durability phase is enriched in potassium. Although boron is a major element in the composition, it was not included in the analysis due to the difficulty of measuring light elements via EDS

mixed in commercially available decorative paint sheens ("Methods") at concentrations ranging from $\sim 1$ to $40 \mathrm{~g} \mathrm{~L}^{-1}$. We observed no changes to the physical properties of the paint beyond a slight pink coloration that varied with concentration of copper-glass ceramic added. The bactericidal efficacy was found to depend on the paint formulation, the paint sheen, and the concentration of the copper-glass ceramic. In this paper, we focus on data at $\sim 26 \mathrm{~g} \mathrm{~L}^{-1}$ of the copper-glass ceramic in an eggshell paint formulation as a typical use case for concentration and paint sheen ("Methods"). Plastic coupons coated with paint containing copper-glass ceramic particles were tested ${ }^{11}$ against four bacteria-the Gram-positive Staphylococcus aureus and the Gram-negative bacteria, Pseudomonas aeruginosa, Klebsiella aerogenes, and Escherichia coli ("Methods"). These bacteria are some of the leading causes of life-threatening hospital-acquired infections and can survive antibiotic intervention to proliferate resistant strains ${ }^{29}$. Greater than or equal to $99.9 \%$ reduction in colony counts of all four bacteria was observed within $2 \mathrm{~h}$ (Fig. 4, inset). S. aureus reduction kinetics show a steady decrease in colony counts over the course of $150 \mathrm{~min}$, with EPA-prescribed 3log kill achieved in $\sim 1 \mathrm{~h}$ (Fig. 4); these results prove that the copper-glass ceramic has potent antibacterial properties.

To test the effectivity of the copper-glass ceramic against viruses, we tested the efficacy of coated coupons against murine norovirus (MNV-1), a test surrogate for human norovirus. Human norovirus is a non-enveloped virus, notorious for causing outbreaks of acute gastrointestinal illness aboard cruise ships. It is highly contagious and transmitted via contaminated surfaces, hand-to-hand contact, and ingesting contaminated food and water. We adapted an antiviral test protocol developed by Haldar et al. ${ }^{30}$ that is consistent with the principles of the EPA protocol for 


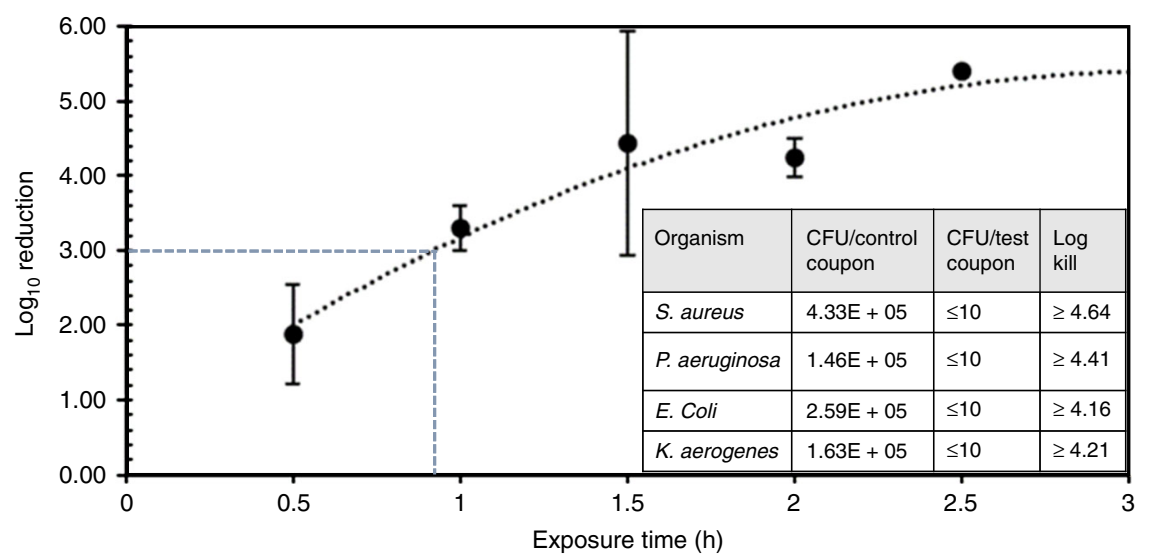

Fig. 4 Bacterial reduction kinetics on paint coupons containing copper glass ceramic particles. Plot of S. aureus reduction as a function of exposure time shows a steady decrease in S. aureus colony counts over $2.5 \mathrm{~h}$, at which point bacterial colonies reduced down to limit of detection. EPA-prescribed 3-log kill (99.9\% reduction) was observed in about $1 \mathrm{~h}$. Data and error bars represent mean and standard deviation from two experiments with samples in triplicate. The inset table showcases the high bactericidal efficacy of copper-glass ceramic particles against S. aureus, P. aeruginosa, E. coli and K. aerogenes. $\geq 4-\log$ kill ( $\geq 99.99 \%$ reduction) was measured against all bacteria following 2-h exposure to test coupons. Bacterial growth on each test and control coupon was measured in triplicate-data shown are geometric mean of values

\section{Table 2 Toxicological profile of copper-glass ceramic powder in animal studies conducted in accordance with US EPA guidelines}

\begin{tabular}{|c|c|c|}
\hline Route of exposure & Study animal & Summary of results \\
\hline $\begin{array}{l}\text { Acute inhalation } \\
\text { toxicity }\end{array}$ & Albino rat & $\mathrm{LC}_{50}>2.29 \mathrm{mg} \mathrm{L}^{-1}$ \\
\hline Acute dermal toxicity & Albino rat & $\mathrm{LD}_{50}>5050 \mathrm{mg} \mathrm{kg}^{-1}$ \\
\hline Acute oral toxicity & Albino rat & $\begin{array}{l}\mathrm{LD}_{50} \text { determined to be } 5000 \\
\mathrm{mg} \mathrm{kg}^{-1}\end{array}$ \\
\hline Acute dermal irritation & Albino rat & Non-irritating to the skin \\
\hline Acute eye irritation & Albino rabbit & Mildly irritating to the eyes \\
\hline Skin sensitization & Guinea pig & Not a skin sensitizer \\
\hline
\end{tabular}

bactericidal efficacy ("Methods"). Complete inactivation of murine norovirus was observed on coated coupon surfaces (Supplementary Table 2).

Copper-glass ceramic was also evaluated as an in-can preservative of paint emulsions. Mainstream organic preservatives such as methylisothiazolinone are added to water-based emulsions to prevent spoilage by bacteria and fungi. Healthrelated risks associated with isothiazolinones ${ }^{31}$ have prompted tough regulatory measures and elicited an urgent search for safer alternatives. Using a standard test method for measuring the resistance of emulsion paints in a container to attack by microorganisms (ASTM D2574) ${ }^{32}$, we observed that the copper-glass ceramic was effective at preventing bacterial contamination by $P$. aeruginosa and Enterobacter aerogenes ( $K$. aerogenes) (Supplementary Table 3 ) at only about $1 / 25$ th the concentration required for passing the EPA test against human pathogens.

Toxicology and potential environmental impact. Animal toxicity studies of finely milled copper-glass ceramic particles revealed no significant concerns (Table 2; "Methods"; Supplementary Data 1; detailed reports available on request). We also evaluated the levels of leached copper from coatings to determine its potential environmental impact. The levels of $\mathrm{Cu}$ ions leached from paint films containing the copper-glass ceramic were studied over 5 days with higher than typical concentrations of the copper-glass ceramic $\left(33 \mathrm{~g} \mathrm{~L}^{-1}\right)$. The level of leached copper was $\sim 550 \mathrm{ppb}$ in the first $24 \mathrm{~h}$, after which it dropped to a steady level of $20-35 \mathrm{ppb} \mathrm{day}^{-1}$ (Supplementary Table 4). These levels are well below the $1300 \mathrm{ppb}$ $\mathrm{Cu} \mathrm{day}^{-1}$ limit set by the EPA for drinking water.

Stability and longevity of antimicrobial potency. We explored the storage stability of the copper-glass ceramic and the ability of coatings containing the material to retain antimicrobial potency through simulated long-term use-considerations that are key to the practical deployment of the material. Accelerated aging studies of the copper-glass ceramic powder to simulate a 1-year period of storage showed no deterioration or corrosion (Supplementary Data 2). We evaluated the long-term potency of the liquid paint and the painted coupons containing the copper-glass ceramic; no decrease in potency was observed over a 6-month study period, suggesting conservation of antimicrobial potency as an additive in an aqueous emulsion and in the dry-film state. To simulate wear-and-tear and ability to withstand cleaning as prescribed by CDC guidelines for infection control, we subjected painted coupons with and without the copper-glass ceramic to rigorous washing and abrasion simulating up to 4 years of wear ("Methods"). Worn test coupons containing the copper-glass ceramic exhibited a $>99.9 \%$ reduction in S. aureus colony counts (Fig. 5) relative to worn control coupons even after 48 cleaning cycles (192 passes of a wet scouring pad on the coating surface). We also evaluated the effect of repeated contamination/soiling of coupons with S. aureus. Control coupons showed an increase in bacterial bioburden following three repeat inoculations (Table 3). By contrast, test coupons demonstrated the ability to continuously reduce bacterial colony counts down to limit of detection. We made copper core-silica shell particles (as described in the literature ${ }^{33}$ ) as an alternative to a glass-ceramic host for $\mathrm{Cu}^{1+}$ ions. These nanoparticles were water dispersible and had an antimicrobial potency similar to the copper-glass ceramic but had to be stored under alcohol to preserve their orange-red color and antimicrobial properties.

The high antimicrobial efficacy ( $\geq 99.9 \%$ microbial reduction in $2 \mathrm{~h}$ ) of the copper-glass ceramic is achieved at very low surface concentrations of copper $(\sim 5 \%)$. An understanding of glass structure-property relationships and the steric constraints with $\mathrm{H}_{3} \mathrm{O}^{+}$ion exchange led us to the copper-glass ceramic material with a fundamentally different mechanism for the release of 


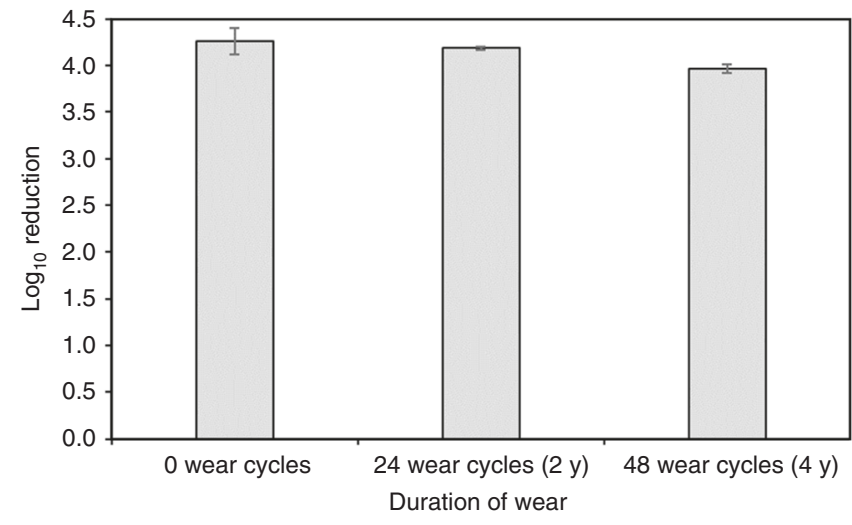

Fig. 5 Efficacy of copper-glass ceramic particles after simulated wear. Plot of antimicrobial potency following washing and abrasion that illustrates longevity of copper-glass ceramic particles. Test paint coatings maintain bactericidal efficacy (>99.9\%) even after 4 years of simulated wear ("Methods"). Each wear cycle represents $4 \times$ washing and abrasion every month. Log reduction calculations are differences in S. aureus colony counts between control and test coupons (both subjected to wear cycles). Data and error bars represent mean and standard deviation from $n=2$ replicates

\begin{tabular}{|c|c|c|}
\hline \multirow[t]{2}{*}{$\begin{array}{l}\text { No. of } \\
\text { inoculations }\end{array}$} & \multicolumn{2}{|c|}{$\begin{array}{l}\text { S. aureus colony counts after } 2 \mathrm{~h} \text { of } \\
\text { exposure (CFU/coupon) }\end{array}$} \\
\hline & Control coupon & Test coupor \\
\hline $\begin{array}{l}1 \\
2 \\
3\end{array}$ & $\begin{array}{l}1.23 E+05 \\
1.85 E+05 \\
8.54 E+06\end{array}$ & $\begin{array}{l}\leq 10 \\
\leq 10 \\
\leq 10\end{array}$ \\
\hline
\end{tabular}

copper ions. The work demonstrates and broadens the scope of rationally designed glasses as hosts for functional nanomaterials. The practical advantages of glass manufacturability contrast with the difficulties of scaling the bottoms up chemical syntheses of air-sensitive nanomaterials or host-guest complexes. Furthermore, the glass itself offers material properties and the potential for chemical functionalization that enable a broad range of applications. In an era of ever increasing concern with infectious diseases and frustration with the performance limitations and safety of organic biocides, the copper-glass ceramic described in this paper is particularly significant.

\section{Methods}

Preparation of glass and glass ceramic. The glass and glass ceramic materials were prepared from boalin sand (Coarse Berkely Fine Special; US Silica), calcined alumina (A2, Unground Classified; Almatis), cupric oxide (325 mesh; Ceramic Color and Chemical), aluminum metaphosphate (Powder, Technical Grade; Chemical Distributors Inc.), technical grade boric acid (Optibor TG; Chemical Distributors Inc.), and potassium carbonate (Food additive grade; Amrex Chemical) raw materials. The raw materials were mixed in a Turbula mixer, then melted for 6 $\mathrm{h}$ at $1600^{\circ} \mathrm{C}$ in covered fused quartz crucibles. The molten glasses were then poured from the crucibles onto a clean stainless-steel table and transferred to annealing furnaces set to the previously determined anneal point for each glass. Glasses were heat treated at the anneal point temperature for $6 \mathrm{~h}$ and then cooled to room temperature at a cooling rate of $100^{\circ} \mathrm{Ch}^{-1}$.

Milling of copper-glass ceramic. The glass samples were hammered into small chunks, magnetically cleaned, and fed into a ceramic disc pulverizer to produce a jet milling feedstock size to pass through a 20 -mesh sieve ( $850-\mu \mathrm{m}$ openings). The glass grains were processed on a ceramic lined laboratory size 2" Sturtevant Micronizer ${ }^{\circledast}$ air jet mill and reduced to a fine micron size powder with a narrow particle distribution. The jet milled powder was then screened at 325 mesh $(45-\mu \mathrm{m}$ openings) to remove any foreign debris and unground particles.

Coupon preparation. Finely milled copper-glass ceramic particles were weighed and mixed with commercial paints (PPG Olympic One, Eggshell Interior Paint, PPG Diamond Interior Paint +Primer) using an overhead stirrer (Fisher Scientific) for 3-5 min to prepare test paint containing $26 \mathrm{~g} \mathrm{~L}^{-1}$ of copper-glass ceramic particles. The emulsion was stirred again for 3-5 min prior to coupon preparation. 1 " $\times 1$ " test coupons (BYK-Gardner 5015 byko-chart black scrub test panels P121$10 \mathrm{~N}$ ) were painted with primer (Zinsser ${ }^{\oplus}$ Bulls Eye 1-2-3 Water-Base Primer; 3 mils) and allowed to dry overnight at ambient temperature and humidity. Two coats of paint (3 mils each) containing copper-glass ceramic were applied sequentially and each layer was allowed to dry for $\geq 24 \mathrm{~h}$. Untreated control coupons were similarly prepared using paints without copper-glass ceramic particles. On the day of testing, coupons were exposed to ultraviolet light (Thermo Scientific 13-Series Class II, Type A2 Biological Safety Cabinet; wavelength $254 \mathrm{~nm}$ ) on both sides for approximately $15 \mathrm{~min}$. Stainless-steel coupons, used as reference surfaces, were cleaned and sterilized by immersion in a $75 \%$ ethanol solution followed by rinsing with deionized (DI) water.

Microorganisms and cell lines. Bacterial strains used were $S$. aureus (ATCC 6538), K. aerogenes (ATCC 13048), P. aeruginosa (ATCC 15442), and E. coli (ATCC 35150). Vials containing each bacterial stock culture were stored at $-80^{\circ} \mathrm{C}$ until use.

Virucidal efficacy tests were conducted at Accuratus Lab Services, MN. Accuratus used murine norovirus, strain S99, obtained from Friedrich-LoefflerInstitut, Greifswald, Germany and conducted infectivity assays using RAW 264.7 cells, a continuous mouse macrophage cell line.

Bactericidal efficacy tests. Bactericidal efficacy tests including study controls were performed as described in the EPA test for efficacy of copper alloy surfaces as a sanitizer ${ }^{11}$. Each coupon was tested in triplicate.

Twenty- $\mu \mathrm{L}$ aliquots of thawed bacterial cultures were added to $10 \mathrm{~mL}$ Tryptic Soy Broth (Teknova). These bacterial suspensions were serially incubated $3 \times$ at $36^{\circ}$ $\mathrm{C}\left(K\right.$. aerogenes at $\left.30^{\circ} \mathrm{C}\right)$ for $18-24 \mathrm{~h}$ in an orbital shaker (New Brunswick Scientific) and then $1 \times$ in polypropylene snap tubes (Fisher Healthcare) for $48 \mathrm{~h}$. Cultures were subsequently mixed on a vortex mixer (VWR Scientific) and allowed to settle. The upper two thirds of suspension from each tube was aspirated and $\mathrm{OD}_{600}$ measured (Smart Spec Spectrophotometer 3000, Bio-Rad) for bacterial density estimation. The culture was diluted with phosphate buffer saline (Gibco Life Technologies) to achieve a bacterial inoculum concentration near a target value of $1.0 \times 10^{7}$ colony-forming units $(\mathrm{CFU}) \mathrm{mL}^{-1}$. Organic soil load containing $0.25 \mathrm{~mL}$ of $5 \%$ fetal bovine serum (Gibco Life Technologies) and 0.05 $\mathrm{mL}$ Triton X-100 (Amresco Pro Pure) was added to $4.70 \mathrm{~mL}$ bacterial suspension to aid in spreading the inoculum.

Each coupon was inoculated with $20 \mu \mathrm{L}$ of the bacterial test culture. The inoculum volume was spread evenly using bent sterile pipette tips (Mettler-Toledo) to ensure full and even coverage, spreading as close to the edge of the coupon as possible. Coupons were then incubated in a controlled environment set at $42 \%$ relative humidity (RH) and $23^{\circ} \mathrm{C}$ for a period of $120 \mathrm{~min}$.

Following the 120-min exposure period, coupons were neutralized in Letheen broth (Gen Lab). Ten-fold serial dilutions of the neutralized solutions were plated using standard spread plate technique on Tryptic Soy Agar plates and incubated for $48 \mathrm{~h}$ at $36^{\circ} \mathrm{C}\left(30^{\circ} \mathrm{C}\right.$ for $K$. aerogenes $)$ to yield countable numbers of survivors (approximately 20-200 colonies per plate).

Simulated wear of copper-glass ceramic particles in coatings. Paint panels containing copper-glass ceramic $\left(26 \mathrm{~g} \mathrm{~L}^{-1}\right)$ were subjected to wear procedure (washing and abrasion), simulating a worst-case scenario of $4 \times$ cleaning every month for up to 4 years.

Simulated wear was performed using an Elcometer 5750 Taber ${ }^{\circledR}$ Linear Abraser Cleaning solution was prepared with a general multipurpose detergent (Best Yet Citrus Cleaner $\left.{ }^{\mathrm{rN}}\right)$ at prescribed dilution in DI water (1:64). A scouring pad (3 M ScotchBrite ${ }^{\circledast}$ Light Duty Cleaning Pad $(1 " \times 1$ ")) was saturated with cleaning solution -2 sprays applied from a distance of $2-3$ ", using a trigger spray bottle (Great Value $\left.{ }^{\mathrm{m} x}\right)$. The pad was attached to an aluminum block attachment (ScotchBrite ${ }^{\circledast}$ Kit, Taber Industries) using double-sided adhesive tape. No additional accessory weights were added to the spline-shaft of the linear abraser (base load of $350 \mathrm{~g}$ ) to keep the pressure similar to that applied in standard paint washability tests such as ASTM D3450. Speed was set to 30 cycles $\mathrm{min}^{-1}$, cycle counter at 2, and stroke length was set to 4". A 1" $\times 4$ " painted panel was secured below the ScotchBrite ${ }^{\circledast}$ pad and 2 cycles were run, representing 1 complete wear cycle (4 passes of the wet scouring pad against the surface). The panel was dried for $\geq 10$ min before the next wear cycle was performed. This process was repeated for 24 cycles (96 passes of the wet scouring pad) to simulate wear and washing for up to 2 years and 48 cycles (192 passes of the wet scouring pad) to simulate cleaning 
for up to 4 years. After completion of wear cycles, panels were cut into 1 " $\times 1$ " coupons and tested for bactericidal efficacy against $S$. aureus (ATCC 6538). Bacterial colony counts on worn test coupons were subtracted from colony counts on similarly worn control coupons to measure reductions.

Continuous cleaning ability of copper-glass ceramic. Three sets of test coupons (containing copper-glass ceramic) and 3 sets of control coupons were used. All coupons were inoculated with $20 \mu \mathrm{L}$ of bacterial inoculum $(t=0)$. Following $2 \mathrm{~h}$ of incubation at $23^{\circ} \mathrm{C}$ and $42 \% \mathrm{RH}$, one test and one control coupon were neutralized and removed for quantitative recovery. The remaining coupons were reinoculated a second time $(t=2 \mathrm{~h})$ with $20 \mu \mathrm{L}$ of culture using a calibrated pipette. Another test and control coupon were removed for quantitative recovery and the remaining set reinoculated a third time $(t=4 \mathrm{~h})$. This set of coupons was neutralized and enumerated at $t=6 \mathrm{~h}$. At each recovery time $(2,4$, and $6 \mathrm{~h})$, control and test coupons were neutralized and enumerated.

Virucidal efficacy tests. Protocol for antiviral efficacy was adapted from Haldar et al. ${ }^{30}$ and conducted at Accuratus Lab Services, MN.

Coupons were inoculated with $20 \mu \mathrm{L}$ murine norovirus using the same procedure used for bacteria and incubated in a controlled chamber set to $\mathrm{RH}$ of $50 \%$ and temperature of $20^{\circ} \mathrm{C}$. After $120 \mathrm{~min}, 1.0 \mathrm{~mL}$ aliquots of $2 \times$ Minimum Essential Medium (Gibco Life Technologies) were pipetted individually onto each test and control coupon. The surface of each coupon was scraped with sterile plastic cell scrapers (Bioscience) and the test medium collected and passed through Sephadex columns (GE Healthcare). The filtrates were then serially diluted ten-fold and assayed for infectivity in RAW 264.7 cells.

Calculations of log and percentage of reductions. Log and percentage of reductions for bactericidal efficacy tests measure differences in CFUs between control and test coupons ${ }^{11}$. For virucidal efficacy tests, $\mathrm{PFU}_{50}$ signifies the concentration at which $50 \%$ of the RAW 264.7 cells are infected when the well plate upon which cells have been cultured is inoculated with a diluted solution of viral fluid from either test or control coupons. Log and percentage of reductions measure differences in $\mathrm{PFU}_{50}$ between control and test coupons.

Acute toxicity testing in animals. Acute toxicity testing was conducted by Stillmeadow Inc, TX. Methods and results are summarized in Supplementary Data 1.

Molecular dynamics simulations. Molecular dynamics simulations were carried out on a cubic sample made up of approximately 2000 atoms with random coordinates equilibrated at $4000 \mathrm{~K}$ for $1 \mathrm{~ns}$. The high temperature melt was quenched to $300 \mathrm{~K}$ continuously over a period of $8 \mathrm{~ns}$ in an NPT (constant number of atoms, constant pressure, and constant temperature) essemble under ambient pressure $^{34}$. Finally, the glass was relaxed at $300 \mathrm{~K}$ under atmospheric pressure for 1 ns. Periodic boundary conditions were applied in all directions. The widely used force field for oxides developed by Pedone et al. ${ }^{35}$ was used. The visualization of the local atomic structure was facilitated by Ovito ${ }^{36}$.

Reporting summary. Further information on research design is available in the Nature Research Reporting Summary linked to this article.

\section{Data availability}

Data generated during and/or analyzed during the current study are included in this published article (and its Supplementary Information file). Detailed reports that support the findings in this study are available from the corresponding author upon reasonable request.

Received: 8 November 2018 Accepted: 8 April 2019

Published online: 30 April 2019

\section{References}

1. Rappuoli, R., Bloom, D. E. \& Black, S. Deploy vaccines to fight superbugs. Nature 552, 165-167 (2017).

2. Davies, J. \& Davies, D. Origins and evolution of antibiotic resistance. Microbiol. Mol. Biol. Rev. 74, 417-433 (2010).

3. Salgado, C. D. et al. Copper surfaces reduce the rate of healthcare-acquired infections in the intensive care unit. Infect. Control Hosp. Epidemiol. 34, 479-486 (2013).

4. Warnes, S. L., Highmore, C. J. \& Keevil, C. W. Horizontal transfer of antibiotic resistance genes on abiotic touch surfaces: implications for public health. mBio 3, e00489-12 (2012).
5. Vincent, M., Duval, R. E., Hartemann, P. \& Engels-Deutsch, M. Contact killing and antimicrobial properties of copper. J. Appl. Microbiol. 124, 1032-1046 (2018)

6. Grass, G., Rensing, C. \& Solioz, M. Metallic copper as an antimicrobial surface. Appl. Environ. Microbiol. 77, 1541-1547 (2011).

7. Thurman, R. B. \& Gerba, C. P. The molecular mechanisms of copper and silver ion disinfection of bacteria and viruses. Crit. Rev. Environ. Control 18, 295-315 (1989).

8. Mathews, S., Kumar, R. \& Solioz, M. Copper reduction and contact killing of bacteria by iron surfaces. Appl. Environ. Microbiol. 81, 6399-6403 (2015).

9. Sunada, K., Minoshima, M. \& Hashimoto, K. Highly efficient antiviral and antibacterial activities of solid-state cuprous compounds. J. Hazard Mater. 235-236, 265-270 (2012).

10. Hans, M. et al. Role of copper oxides in contact killing of bacteria. Langmuir 29, 16160-16166 (2013).

11. United States Environmental Protection Agency. Test Method for Efficacy of Copper Alloy Surfaces as a Sanitizer (United States Environmental Protection Agency, Washington DC, 2008).

12. Michels, H. T. \& Anderson, D. G. Metal Ions in Biology and Medicine, Vol. 10 (eds Collery, P. et al.) (John Libbey Eurotext, Montrouge, 2008).

13. Rosenberg, M. et al. Rapid in situ assessment of $\mathrm{Cu}$-ion mediated effects and antibacterial efficacy of copper surfaces. Sci. Rep. 8, https://doi.org/10.1038/ s41598-018-26391-8 (2018).

14. Michels, H. T., Noyce, J. O. \& Keevil, C. W. Effects of temperature and humidity on the efficacy of methicillin- resistant Staphylococcus aureus challenged antimicrobial materials containing silver and copper. Lett. Appl. Microbiol. 49, 191-195 (2009).

15. Morse, D. L. \& Evenson, J. W. Welcome to the glass age. Int. J. Appl. Glass Sci. 7, 409-412 (2016)

16. Norton, F. J. Permeation of gaseous oxygen through vitreous silica. Nature 191, 701 (1961)

17. Matusita, K. \& Mackenzie, J. D. Low expansion copper aluminosilicate glasses. J. Noncryst. Solids 30, 285-292 (1979).

18. Matusita, K., Sakka, S. \& Shouji, T. Thermal expansion of substituted copper aluminosilicate glasses. J. Am. Ceram. Soc. 66, 33-35 (1983).

19. Doremus, R. H. Interdiffusion of hydrogen and alkali ions in a glass surface. $J$. Noncryst. Solids 19, 137-144 (1975).

20. Lanford, W. A. et al. Hydration of soda-lime glass. J. Noncryst. Solids 33, 249-266 (1979).

21. Quaranta, A. et al. Formation of copper nanocrystals in alkali-lime silica glass by means of different reducing agents. J. Noncryst. Solids 345-346, 671-675 (2004).

22. Swarts, E. L. Introduction to Glass Science (Plenum Press, New York, 1972).

23. Shannon, R. D. Revised effective ionic radii and systematic studies of interatomic distances in halides and chalcogenides. Acta Crystallogr. A 32, 751-767 (1976).

24. Bradley, L. C. et al. Hydronium ions in soda-lime silicate glass surfaces. J. Am. Ceram. Soc. 96, 458-463 (2013).

25. Doremus, R. H. Exchange and diffusion of ions in glass. J. Phys. Chem. 68, 2212-2218 (1964)

26. Gehrke, E., Ullner, C. \& Hähnert, M. Fatigue limit and crack arrest in alkalicontaining silicate glasses. J. Mater. Sci. 26, 5445-5455 (1991).

27. Tomozawa, M. Treatise on Materials Science and Technology, Vol. 17 (Academic Press, New York, London, 1979).

28. Ma, L., Brow, R. K. \& Schlesinger, M. E. Dissolution behavior of $\mathrm{Na}_{2} \mathrm{O}-\mathrm{FeO}-\mathrm{Fe}_{2} \mathrm{O}_{3}-\mathrm{P}_{2} \mathrm{O}_{5}$ glasses. J. Noncryst. Solids 463, 90-101 (2017).

29. Pendleton, J. N., Gorman, S. P. \& Gilmore, B. F. Clinical relevance of the ESKAPE pathogens. Expert Rev. Antiinfect. Ther. 11, 297-308 (2013).

30. Haldar, J., Weight, A. K. \& Klibanov, A. M. Preparation, application and testing of permanent antibacterial and antiviral coatings. Nat. Protoc. 2 , 2412-2417 (2007)

31. Amsler, E. et al. Airborne allergic contact dermatitis caused by isothiazolinones in water-based paints: a retrospective study of 44 cases. Contact Dermat. 77, 163-170 (2017).

32. ASTM D2574-16. Standard Test Method for Resistance of Emulsion Paints in the Container to Attack by Microorganisms (ASTM International, West Conshohocken, PA, 2016)

33. $\mathrm{Su}, \mathrm{X}$. et al. A facile synthesis of $\mathrm{Cu}_{2} \mathrm{O} / \mathrm{SiO}$ and $\mathrm{Cu} / \mathrm{SiO}_{2}$ core-shell octahedral nanocomposites. Nanotechnology 19, 365610 (2008).

34. Nosé, S. A unified formulation of the constant temperature molecular dynamics methods. J. Chem. Phys. 81, 511-519 (1984).

35. Pedone, A., Malavasi, G., Menziani, M. C., Cormack, A. N. \& Segre, U. A new self-consistent empirical interatomic potential model for oxides, silicates, and silicas-based glasses. J. Phys. Chem. B 110, 11780-11795 (2006)

36. Stukowski, A. Visualization and analysis of atomistic simulation data with OVITO-the Open Visualization Tool. Modelling Simul. Mater. Sci. Eng. 18, $015012(2010)$ 


\section{Acknowledgements}

We thank Dr. Victor Jin for concentration studies of the copper-glass ceramic in paint; Kaitlyn Matias for antimicrobial testing on copper-glass coupons; Erika L. Stapleton for XRD analysis; Dr. Bavani Balakrisnan and Daniel A. Sternquist for ICP and redox chemistry analysis; Dr. Ying Zhang, Guohua Chen, and Dr. John Wang for work on silica shell nanoparticles; Shawn T. Barkley for powder preparation and characterization; and Dr. Randall E. Youngman for NMR analysis. We also thank Professor Stephen J. Benkovic, Dr. Gary S. Calabrese, Martin J. Curran, Professor Chad A. Mirkin, Dr. David L. Morse, Professor Thomas E. Shenk, and Wendell P. Weeks for critical feedback.

\section{Author contributions}

T.M.G. created the copper-glass and copper-glass ceramic compositions. T.M.G., J.La. and A.G. provided critical input and wrote the manuscript. J.Lu. conducted molecular dynamics simulations. AM efficacy was measured by F.V. and J.L.K. J.W. performed STEM analysis. D.E.B. performed SEM analysis. P.F.N. prepared test coupons. M.J.S. conducted melts of copper-glass ceramic.

\section{Additional information}

Supplementary Information accompanies this paper at https://doi.org/10.1038/s41467019-09946-9.

Competing interests: T.M.G., J.La., A.G., J.Lu., P.F.N., F.V., J.L.K., D.E.B., and M.J.S. are employees of Corning Incorporated. J.W. was an employee of Corning Incorporated at the time of this study.

Reprints and permission information is available online at http://npg.nature.com/ reprintsandpermissions/

Journal peer review information: Nature Communications thanks Belén Cabal, Katherine Zodrow, and other anonymous reviewer(s) for their contribution to the peer review of this work.

Publisher's note: Springer Nature remains neutral with regard to jurisdictional claims in published maps and institutional affiliations.

\section{(c) (i)} adaptation, distribution and reproduction in any medium or format, as long as you give appropriate credit to the original author(s) and the source, provide a link to the Creative Commons license, and indicate if changes were made. The images or other third party material in this article are included in the article's Creative Commons license, unless indicated otherwise in a credit line to the material. If material is not included in the article's Creative Commons license and your intended use is not permitted by statutory regulation or exceeds the permitted use, you will need to obtain permission directly from the copyright holder. To view a copy of this license, visit http://creativecommons.org/ licenses/by/4.0/

(C) The Author(s) 2019 